\title{
Intellectual Capital, Leverage dan Profitabilitas Perusahaan Sub-Sektor Asuransi di Bursa Efek Indonesia
}

\author{
Putu Winda Agastya Paramita ${ }^{1}$ \\ Fakultas Ekonomi dan Bisnis \\ Universitas Udayana, Indonesia
}

\author{
I Gusti Ayu Made Asri Dwija Putri2 \\ Fakultas Ekonomi dan Bisnis \\ Universitas Udayana, Indonesia
}

Surel : agastyaparamita@gmail.com

\section{ABSTRAK}

Kinerja keuangan perusahaan dapat digunakan sebagai alat untuk mengukur tingkat kesehatan suatu perusahaan secara keseluruhan. Indikator yang sering digunakan untuk mengukur kinerja keuangan perusahaan salah satunya adalah profitabilitas. Profitabilitas adalah tingkat kemampuan perusahaan dalam menghasilkan keuntungan dan mengukur efisiensi operasional dan efisiensi penggunaan harta yang dimilikinya. Terdapat beberapa faktor yang diduga mempengaruhi profitabilitas diantaranya adalah intellectual capital dan leverage. Penelitian ini bertujuan untuk mengetahui pengaruh intellectual capital dan leverage pada profitabilitas perusahaan. Penelitian ini dilakukan pada 11 perusahaan sub-sektor asuransi yang terdaftar di Bursa Efek Indonesia Tahun 2016-2018. Teknik penentuan sampel yang digunakan adalah non probability sampling dengan metode purpose sampling. Teknik analisis yang digunakan dalam penelitian ini adalah regresi linier berganda. Hasil akhir menunjukkan bahwa intellectual capital berpengaruh positif pada profitabilitas dan leverage berpengaruh negatif pada profitabilitas perusahaan.

Kata Kunci: Intellectual Capital; Leverage; Profitabilitas.

Intellectual Capital, Leverage and Profitability of Insurance Sub-Sector Companies on the Indonesia Stock Exchange

\begin{abstract}
The company's financial performance can be used as a tool to measure the overall level of health of a company. One indicator that is often used to measure a company's financial performance is profitability. Profitability is the level of a company's ability to generate profits and measure operational efficiency and the efficiency of the use of its assets. There are several factors that are thought to affect profitability including intellectual capital and leverage. This study aims to determine the effect of intellectual capital and leverage on company profitability. This research was conducted on 11 insurance sub-sector companies listed on the Indonesia Stock Exchange in 2016-2018. The sampling technique used is non probability sampling with the purpose sampling method. The analysis technique used in this study is multiple linear regression. The final results show that intellectual capital has a positive effect on profitability and leverage has a negative effect on company profitability.
\end{abstract}

Keywords: $\quad$ Intellectual Capital; Leverage; Profitability.

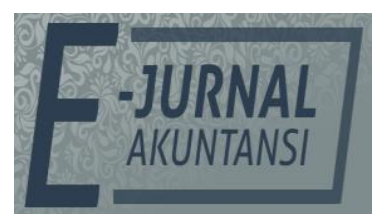

e-ISSN 2302-8556

Vol. 30 No. 12

Denpasar, Desember 2020

Hal. 3110-3120

DOI:

10.24843/EJA.2020.v30.i12.p09

PENGUTIPAN:

Paramita, P.W.A. \& Putri, I G.A.M.A.D. (2020).

Intellectual Capital, Leverage dan Profitabilitas

Perusahaan Sub-Sektor Asuransi di Bursa Efek Indonesia. E-Jurnal Akuntansi, 30(12), 3110-3120

RIWAYAT ARTIKEL: Artikel Masuk: 28 Januari 2020 Artikel Diterima: 16 Maret 2020

Artikel dapat diakses : https://ojs.unud.ac.id/index.php/Akuntansi/index 


\section{PENDAHULUAN}

Kinerja keuangan perusahaan diperlukan sebagai salah satu alat untuk mengukur tingkat kesehatan suatu perusahaan. Kinerja keuangan merupakan faktor penting yang dapat digunakan untuk menilai keseluruhan kinerja perusahaan yang terdiri dari aset, utang, dan likuiditas. Salah satu indikator yang dapat digunakan untuk mengukur kinerja keuangan suatu perusahaan adalah profitabilitas. Profitabilitas adalah tingkat kemampuan perusahaan dalam menghasilkan keuntungan dan mengukur efisiensi operasional dan efisiensi penggunaan hartanya (Chen \& Chen, 2011). Alat ukur yang sering digunakan untuk mengukur tingkat profitabilitas adalah Return on Asset (ROA) karena merupakan rasio paling baik yang dapat memprediksikan penumbuhan laba. Dewi \& Wirawati (2018) juga mengemukakan bahwa ROA merupakan ukuran protitabilitas yang lebih baik dari rasio profitabilitas lainnya karena rasio ini dapat mengukur efesiensi operasi perusahaan.

Profitabillitas perusahaan sub-sektor asuransi yang diukur dengan menggunakan ROA mengalami penurunan dari tahun 2016-2018. Pada tahun 2016 rata-rata ROA perusahaan sub-sektor asuransi adalah 4,83\%, mengalami penurunan pada tahun 2017 menjadi 3,26\% dan mengalami penurunan lagi menjadi $2,39 \%$ pada tahun 2018. Industri asuransi adalah salah satu industri lembaga keuangan non bank yang memiliki peran penting dalam sistem keuangan Indonesia. Industri ini memiliki pangsa pasar terbesar kedua setelah perbankan dan merupakan pemegang pangsa pasar terbesar untuk industri lembaga keuangan non bank (Damayanti et al., 2018).

Terdapat beberapa faktor yang diduga memiliki pengaruh terhadap profitabilitas suatu perusahaan salah satunya adalah intellectual capital. Standar Akuntansi Keuangan (PSAK) No. 19 tentang aktiva tidak berwujud menyatakan bahwa aktiva non-moneter yang dapat diidentifikasi dan tidak mempunyai wujud fisik yang akan digunakan dalam menghasilkan atau menyerahkan barang atau jasa, disewakan kepada pihak lainnya, atau untuk tujuan administratif. PSAK No. 19 inilah yang mempelopori muncunya fenomena mengenai modal intelektual di Indonesia, walaupun tidak secara eksplisit dijabarkan. Menurut Mondal \& Ghosh (2012) istilah intellectual capital digunakan untuk menjelaskan aset tidak berwujud atau faktor bisnis tidak berwujud perusahaan, yang memiliki dampak signifikan terhadap kinerja dan keberhasilan bisnis secara keseluruhan, meskipun secara eksplisit tidak tercantum dalam neraca.

Menurut Stewart \& Ruckdeschel (1998) definisi modal intelektual secara operasional adalah sebagai bahan intelektual yang telah diformalkan, ditangkap, dan dimanfaatkan untuk menghasilkan aset bernilai lebih tinggi. Abhayawansa et. al., (2018) mengungkapkan bahwa elemen modal intelektual dapat bervariasi, dinamis, dan transformatif. Abhayawansa \& Guthrie (2014) menjelaskan bahwa dalam berkontribusi pada nilai perusahaan, peran, dan hubungan elemen modal intelektual (IC) tidak dapat ditentukan secara apriori tetapi sangat bergantung pada elemen dan konstruksi dalam proses penciptaan nilai perusahaan. Para ahli banyak menyatakan bahwa intellectual capital terdiri dari tiga elemen utama (Sawarjuwono \& Kadir, 2003), yaitu: Human capital (modal manusia), Structural 
Capital atau Organizational Capital (modal organisasi) dan Relational Capital atau Costumer Capital (modal pelanggan).

Faktor lain yang bisa mempengaruhi tingkat profitabilitas suatu perusahaan adalah leverage. Leverage mampu menjelaskan bagaimana kemampuan perusahaan untuk memenuhi kewajiban finansialnya (Raharja \& Putra, 2016). Leverage adalah alat ukur yang dapat digunakan untuk mengukur seberapa besar tingkat ketergantungan perusahaan pada kreditur dalam pembiayaan asetnya. Apabila perusahaan memiliki leverage yang tinggi artinya perusahaan tersebut memiliki ketergantungan yang tinggi pula terhadap pinjaman dari pihak luar dalam pembiayaan asetnya.

Isbanah (2015) menjelaskan bahwa leverage merupakan pengukur aktiva yang dibiayai dengan hutang. Menurut Brigham \& Houston (2001) leverage dibedakan menjadi dua jenis yaitu financial leverage dan leverage operasi. Financial leverage merupakan ukuran yang menunjukkan tingkat sekuritas berpenghasilan tetap (hutang dan saham preferen) yang digunakan dalam struktur modal perusahaan. Financial leverage terjadi apabila perusahaan menggunakan pembiayaan berupa dana yang menimbulkan beban tetap bagi perusahaan, salah satunya adalah dengan menggunakan hutang. Leverage operasi merupakan biaya tetap yang digunakan dalam pelaksanaan operasional perusahaan. Leverage operasi merupakan suatu indikator perubahan laba bersih yang diakibatkan oleh volume penjualan (Suwito \& Herawati, 2005).

Teori berbasis sumberdaya atau resource based theory merupakan teori yang menjelaskan intellectual capital. Teori RBT ini pertama kali diperkenalkan oleh Wernerfelt (1984). Teori ini menjelaskan apabila perusahaan bisa mengelola sumber daya dan pengetahuannya dengan baik maka perusahaan tersebut akan memiliki keunggulan kompetitif yang akan mempengaruhi kinerja perusahaan. Keunggulan kompetitif yang dimiliki oleh sebuah perusahaan dapat berupa kepemilikan dan pemanfaatan dengan efektif sumber daya organisasi yang mampu menambah nilai (valuable), bersifat langka (rare), sulit untuk ditiru (imperfectly immitable), dan tidak tergantikan oleh sumberdaya lain (nonsubstitutable). Perusahaan dapat mengungguli pesaing usahanya dan menghasilkan kinerja keuangan yang baik dengan cara memiliki, menguasai dan memanfaatkan aset-aset strategis yang memiliki potensi (aset berwujud maupun tidak berwujud). Oleh karena itu, perusahaan harus mampu mencari, mendapatkan, mengembangkan, dan mempertahankan sumber daya strategis agar memiliki keunggulan bersaing. Sumber daya staregis yang dimaksud adalah intellectual capital .

Menurut Mariyantini \& Putri (2018) intellectual capital memiliki pengaruh positif pada kinerja keuangan perusahaan. Hal ini juga sejalan dengan resource based theory, yang menyatakan apabila perusahaan dapat memberdayakan modal intelektual secara efektif dan efisien sehingga dapat menekan biaya-biaya perusahaan. Hal tersebut akan meningkatkan penjualan barang atau jasa perusahaan, terlebih lagi dengan adanya penurunan biaya-biaya akan meningkatkan laba bagi perusahaan, sehingga kinerja keuangan perusahaan juga akan meningkat. Prastuti \& Budiasih (2019), Ariyani \& Wirakusuma (2018) serta Fitriasari \& Sari (2019) juga menyatakan bahwa intellectual capital berpengaruh pofitif pada profitabilitas. Berdasarkan hasil penelitian terdahulu dan landasan 
teori yang ada, maka hipotesis yang dirumuskan dalam penelitian ini ebagai berikut.

$\mathrm{H}_{1}$ : Intellectual capital berpengaruh positif pada profitabilitas.

Teori struktur modal atau trade-off theory menjelaskan mengenai keseimbangan antara manfaat dan pengorbanan dalam menggunakan utang (Brigham \& Houston, 2001). Artinya apabila perusahaan memiliki tingkat hutang yang semakin tinggi, maka semakin tinggi pula beban tetap perusahaan sehingga akan meningkatkan risiko kesulitan keuangan pada perusahaan. Hal ini dapat mempengaruhi profitabilitas karena apabila tingkat hutang semakin tinggi maka kemampuan perusahaan dalam menghasilkan laba akan semakin rendah, perusahaan akan lebih memprioritaskan untuk membayar hutang daripada meningkatkan profitabilitasnya. Penelitian Andreani \& Putra (2019) menyatakan bahwa leverage berpengaruh negatif terhadap profitabilitas. Hal ini artinya apabila tingkat utang semakin tinggi, maka beban tetap semakin besar sehingga akan meningkatkan risiko kesulitan keuangan. Hal ini juga sejalan dengan hasil penelitian Lais Khafa (2015) dan Isbanah (2015) yang menyatakan debt to asset ratio berpengaruh negatif pada profitabilitas. Berdasarkan hasil penelitian terdahulu dan landasan teori yang ada, maka hipotesis yang dapat dirumuskan sebagai berikut.

$\mathrm{H}_{2}$ : Leverage berpengaruh negatif pada profitabilitas.

\section{METODE PENELITIAN}

Penelitian ini berlokasi di perusahaan sub-sektor asuransi yang terdaftar di Bursa Efek Indonesia periode 2016-2018 yang diakses melalui website www.idx.co.id. Obyek dalam penelitian ini adalah profitabilitas perusahaan sub-sektor asuransi yang terdaftar di Bursa Efek Indonesia periode 2016-2018 yang diduga dipengaruhi oleh intellectual capital dan leverage.

Intellectual capital adalah segala bentuk harta tidak berwujud yang berupa kekayaan intelektual yang dimiliki oleh suatu perusahaan yang apabila dikembangkan secara optimal dapat memberikan keuntungan bagi perusahaan di masa mendatang. Intellectual capital dalam penelitian ini diukur dengan menggunakan Value Added Intellectual Coefficient (VAIC). VAIC merupakan instrumen yang digunakan untuk mengukur intellectual capital perusahaan dengan menggunakan informasi yang diperoleh dari laporan keuangan. Pengukuran intellectual capital menggunakan VAIC adalah sebagai berikut.

$V A=O U T-I N$

Keterangan:

VA = selisih antara output dan input

OUT = total penjualan dan pendapatan lain

IN = seluruh biaya dan beban perusahaan, kecuali biaya karyawan

VACA $=\frac{V A}{\text { CapitalEmployed. }}$

Keterangan:

VA $\quad$ = selisih antara output dan input

Capital Employed = dana yang tersedia (ekuitas dan laba bersih) 
VAHU $=\frac{V A}{\text { Human Capital }}$

Keterangan:

VA = selisih antara output dan input

Human Capital = beban karyawan yang terdiri dari gaji dan tunjangan

STVA $=\frac{\text { Structral Capital }}{V A}$

Keterangan:

VA $\quad$ = selisih antara output dan input

Structural Capital $=V A-$ Human Capital

$\mathrm{VAIC}=\mathrm{VACA}+\mathrm{VAHU}+\mathrm{STVA}$

Leverage adalah rasio yang digunakan untuk mengukur besarnya kebutuhan dana perusahaan yang dibiayai oleh utang. Dalam penelitian ini leverage diukur dengan menggunakan Debt to Equity Ratio (DER). Rasio ini menggambarkan perbandingan antara utang dan modal sendiri. DER dapat dirumuskan sebagai berikut.

$D E R=\frac{\text { totalkewajiban }}{\text { total ekwitas }}$

Profitabilitas mencerminkan kemampuan suatu perusahaan untuk menghasilkan keuntungan. Profitabilitas dalam penelitian ini diukur dengan menggunakan Return on Asset (ROA). ROA adalah rasio yang mampu menggambarkan kemampuan efisiensi suatu perusahaan dalam menghasilkan laba atau keuntungan dengan memanfaatkan aset yang dimilikinya. Semakin besar nilai ROA, maka semakin baik pula kinerja keuangan perusahaan. Rumus untuk menghitung ROA adalah sebagai berikut.

ROA $=\frac{\text { lababersihsetelahpajak }}{\text { total aset }}$

Sampel adalah bagian dari jumlah maupun karakteristik yang dimiliki oleh populasi tersebut (Sugiyono, 2018). Sampel dalam penelitian ini adalah 11 perusahaan sub-sektor asuransi yang terdaftar di Bursa Efek Indonesia dengan periode amatan tiga tahun yaitu tahun 2016-2018. Teknik pengambilan sampel yang digunakan dalam penelitian ini adalah non-probability sampling dengan teknik purposive sampling.

Penelitian ini menggunakan teknik regresi linier berganda untuk menganalisis data. Analisis regresi linier berganda mrupakan analisis yang digunakan untuk mengetahui hubungan antara satu variabel terikat (dependent) dan lebih dari satu variabel bebas (independet). Tujuan dilakukannya uji regresi linier berganda adalah untuk mengetahui pengaruh intellectual capital dan leverage pada profitabilitas perusahaan sub-sektor asuransi. Adapun persamaan regresinya adalah sebagai berikut.

$Y=\alpha+\beta_{1} X_{1}+\beta_{2} X_{2}+\varepsilon$

Keterangan:

$\mathrm{Y}=$ Profitabilitas perusahaan asuransi yang terdaftar di BEI periode 2016-2018

a $\quad=$ Nilai konstanta

$\beta_{1} \quad=$ Koefisien regresi intellectual capital

$\mathrm{X}_{1} \quad=$ Intellectual Capital

$\beta_{2} \quad=$ Koefisien regresi leverage 
$\mathrm{X}_{2} \quad=$ Leverage

$\varepsilon \quad=$ Error term

\section{HASIL DAN PEMBAHASAN}

Industri asuransi merupakan salah satu industri lembaga keuangan non bank yang berperan penting dalam sistem keuangan Indonesia. Industri ini memiliki pangsa pasar kedua terbesar setelah perbankan dan merupakan pemegang pangsa pasar terbesar dalam industri lembaga keuangan non bank (Damayanti et al., 2018). Berikut ini merupakan tabel yang menunjukkan proses penentuan sampel.

\section{Tabel 1. Proses Penentuan Sampel Penelitian}

\begin{tabular}{lc}
\hline Kriteria & Jumlah \\
\hline $\begin{array}{l}\text { Populasi penelitian adalah perusahaan sub-sektor asuransi yang } \\
\text { terdaftar di Bursa Efek Indonesia periode 2016-2018 }\end{array}$ & 12 \\
1 Perusahan sub-sektor asuransi yang tidak mempublikasikan & $(0)$ \\
laporan keuangan tahunan selama periode 2016-2018. & \\
2 Perusahan sub-sektor asuransi yang tidak melaporkan laba positif & $(1)$ \\
$\quad$ dalam laporan tahunan selama periode 2016-2018. & \\
$3 \begin{array}{l}\text { Perusahan sub-sektor asuransi yang laporan keuangannya tidak } \\
\text { memuat seluruh data yang terkait dengan intellectual capital dan }\end{array}$ & $(0)$ \\
$\quad$ leverage selama periode 2016-2018. & \\
$4 \begin{array}{l}\text { Perusahaan sub-sektor asuransi yang tidak melaporkan laporan } \\
\text { keuangan menggunakan mata uang rupiah. }\end{array}$ & $(0)$ \\
$\begin{array}{l}\text { Total sampel penelitian } \\
\text { Tahun pengamatan }\end{array}$ & 11 \\
Total sampel selama periode penelitian & 3 \\
\hline
\end{tabular}

Sumber: Bursa Efek Indonesia, 2019

Berdasarkan Tabel 1, dapat diketahui bahwa sampel dalam penelitian ini adalah 11 perusahaan selama periode amatan 3 tahun, sehinga jumlah sampel dalam penelitian ini adalah 33 .

Statistik deskriptif variabel penelitian menjelaskan tentang karakteristik variabel-variebel yang digunakan dalam penelitian. Statistik deskriptif terdiri dari jumlah amatan, nilai minimum, nilai maksimum, nilai rata-rata (mean) dan standar deviasi. Nilai rata-rata (mean) merupakan cara umum yang digunakan untuk mengukur nilai sentral dan suatu distribusi data. Standar deviasi digunakan untuk mengukur seberapa luas atau seberapa jauh penyimpangan data dari nilai rata-ratanya. Hasil statistik deskriptif ditampilkan dalam Tabel 2, berikut.

Tabel 2. Hasil Uji Statistik Deskriptif Variabel Penelitian

\begin{tabular}{llllll}
\hline Variabel & $\begin{array}{l}\text { Jumlah } \\
\text { sampel }\end{array}$ & $\begin{array}{l}\text { Nilai } \\
\text { Minimum }\end{array}$ & $\begin{array}{l}\text { Nilai } \\
\text { Maximum }\end{array}$ & $\begin{array}{l}\text { Nilai } \\
\text { Rata-rata }\end{array}$ & $\begin{array}{l}\text { Standar } \\
\text { Deviasi }\end{array}$ \\
\hline VAIC & 33 & 1.71 & 9.90 & 3.96 & 2.28 \\
DER & 33 & .17 & 3.62 & 1.38 & .87 \\
ROA & 33 & 1.51 & 8.81 & 4.66 & 1.87 \\
Valid N (listwise) & 33 & & & & \\
\hline
\end{tabular}

Sumber: Data Penelitian, 2019

Profitabilitas dalam penelitian ini diukur dengan Return on Assets (ROA). Nilai minimum ROA yaitu sebesar 1,51 persen dan nilai maksimum sebesar 8,81 persen. Rata-rata ROA sebesar 4,66 persen dengan standar deviasi sebesar 1,87 
persen. Nilai standar deviasi yang lebih kecil dari nilai rata-rata memiliki arti bahwa variabel profitabilitas memiliki sebaran yang kecil. Intellectual capital dalam penelitian ini diukur dengan menggunakan Value Added Intellectual Capital (VAIC). Nilai minimum VAIC yaitu sebesar 1,71 dan nilai maksimum sebesar 9,90. Rata-rata VAIC sebesar 3,96 dengan standar deviasi sebesar 2,28. Nilai standar deviasi yang lebih kecil dari nilai rata-rata artinya variabel intellectual capital memiliki sebaran data yang relatif kecil. Leverage dalam penelitian ini diukur dengan menggunakan Debt to Equity Ratio (DER). Nilai minimum DER yaitu sebesar 0,17 dan nilai maksimum sebesar 3,62. Rata-rata DER sebesar 1,38 dengan standar deviasi sebesar 0,87 persen. Nilai standar deviasi yang lebih kecil dari nilai rata-rata memiliki arti bahwa variabel intellectual capital memiliki sebaran data yang relatif kecil.

Penelitian ini menggunakan teknik regresi linier berganda untuk menganalisis data, sehingga memerlukan uji asumsi klasik sebagai salah satu syaratnya. Berikut merupakan tabel hasil uji asumsi klasik.

Tabel 3. Hasil Uji Asumsi Klasik

\begin{tabular}{lll}
\hline Uji Asumsi Klasik & Hasil Uji & Keterangan \\
\hline Uji normalitas & Asymp. Sig. (2-tailed) sebesar & Berdistribusi normal \\
& $0,480 \geq 0,05$. & \\
Uji multikolinearitas & Tolerance $(1,00) ;(1,00) \leq 10 \%$ & Bebas dari \\
& VIF $(1,00) ;(1,00) \leq 10$ & multikolinearitas \\
Uji autokorelasi & $\mathrm{dU}=1,57<\mathrm{dW}=2,09<4$-dU $=$ & Tidak terjadi autokorelasi \\
& $2,44, \quad$ & \\
Uji heteroskedastisitas & Sig. $(0,34) ;(0,95) \leq 0,05$ & Tidak terjadi \\
& & heteroskedastisitas \\
\hline
\end{tabular}

Sumber: Data Penelitian, 2019

Analisis regresi linier berganda digunakan untuk menganalisis pengaruh antara variabel bebas yaitu intellectual capital (X1) dan leverage (X2) terhadap variabel terikat yaitu profitabilitas $(\mathrm{Y})$. Perhitungan koefisien regresi linier berganda dilakukan dengan analisis regresi melalui software SPSS 20.0 for Windows, yang hasilnya adalah sebagai berikut.

Tabel 4. Hasil Analisis Regresi Linier Berganda

\begin{tabular}{|c|c|c|c|c|c|}
\hline \multirow[b]{2}{*}{ Model } & \multicolumn{2}{|c|}{ Unstandardized Coefficients } & \multicolumn{2}{|l|}{$\begin{array}{l}\text { Standardized } \\
\text { Coefficients }\end{array}$} & \multirow[b]{2}{*}{ Sig. } \\
\hline & $\mathrm{B}$ & Std. Error & Beta & $t$ & \\
\hline 1 (Constant) & -.166 & .12 & & -1.36 & .180 \\
\hline VAIC & .402 & .13 & .46 & 3.00 & .005 \\
\hline DER & -.227 & .11 & -.32 & -2.07 & .047 \\
\hline
\end{tabular}

Sumber: Data Penelitian, 2019

Berdasarkan Tabel 4, dapat dilihat bahwa persamaan regresi dalam penelitian ini adalah sebagai berikut.

$$
Y=-0,166+0,402 X_{1}-0,227 X_{2}+\varepsilon
$$

Nilai konstanta (a) sebesar -0,166 artinya jika nilai intellectual capital dan leverage sama dengan nol, maka besarnya profitabilitas yang diukur dengan menggunakan ROA adalah -0,166 dengan asumsi variabel lain konstan. Nilai koefisien regresi $\left(\beta_{1}\right)$ dari variabel intellectual capital adalah 0,402 memiliki arti apabila variabel intellectual capital mengalami kenaikan sebesar satu satuan, maka profitailitas meningkat sebesar 0,402 satuan dengan asumsi variabel lain konstan. 
Nilai koefisien regresi $\left(\beta_{2}\right)$ dari variabel leverage adalah $-0,227$ memiliki arti apabila variabel leverage mengalami kenaikan sebesar satu satuan, maka profitailitas menurun sebesar 0,227 satuan dengan asumsi variabel lain konstan.

Uji koefisien determinasi dilakukan untuk mengetahui seberapa besar variabel independen yang digunakan dalam penelitian mampu menjelaskan variabel dependen. Nilai koefisien determinasi adalah antara 0 (nol) dan 1 (satu). Nilai adjusted $\mathrm{R}^{2}$ yang semakin mendekati 1 (satu) artinya variabel-variabel independen memberikan hampir semua informasi yang dibutuhkan untuk menjelaskan variabel dependennya. Adapun nilai adjusted $\mathrm{R}^{2}$ dalam penelitian ini disajikan dalam Tabel 5.

Tabel 5. Koefisien Determinasi

\begin{tabular}{cllll} 
Model & $\mathrm{R}$ & $\mathrm{R}$ Square & Adjusted R Square & Std. Error of the Estimate \\
\hline 1 & $.550^{\mathrm{a}}$ & .303 & .256 & .686
\end{tabular}

Sumber: Data Penelitian, 2019

Berdasarkan Tabel 5, dapat dilihat bahwa nilai Adjusted R2 sebesar 0,256 yang artinya $25,6 \%$ variasi perubahan profitabilitas dapat dijelaskan oleh variabel intellectual capital dan leverage. Sedangkan sisanya sebesar 74,4\% dipengaruhi oleh variabel lain di luar model.

Tabel 6. Hasil Uji Kelayakan Model (Uji F)

\begin{tabular}{|c|c|c|c|c|c|}
\hline \multirow{2}{*}{ Regression } & Sum of Squares & Df & Mean Square & $\mathrm{F}$ & Sig. \\
\hline & 6.138 & 2 & 3.07 & 6.52 & $.004^{\mathrm{a}}$ \\
\hline Residual & 14.12 & 30 & .471 & & \\
\hline Total & 20.26 & 32 & & & \\
\hline
\end{tabular}

Sumber: Data Penelitian, 2019

Hasil uji $\mathrm{F}$ menunjukkan bahwa nilai $\mathrm{F}$ hitung sebesar 6,52 dengan nilai signifikansi p-value 0,004 yang nilainya $\geq 0,05$, yang artinya model dalam penelitian ini layak uji dan dapat disimpulkan bahwa terdapat pengaruh antara intellectual capital $\left(\mathrm{X}_{1}\right)$ dan leverage $\left(\mathrm{X}_{2}\right)$ terhadap varaibel terikat yaitu profitabilitas $(\mathrm{Y})$ secara simultan.

Tabel 7. Hasil Uji Hipotesis (Uji t)

\begin{tabular}{llllll}
\hline \multicolumn{7}{c}{ Model } & \multicolumn{5}{c}{ Standardized } \\
\cline { 2 - 5 } & $\mathrm{B}$ & Std. Error & Beta & $\mathrm{T}$ & Sig. \\
\hline 1 (Constant) & -.166 & .122 & & -1.361 & .184 \\
VAIC & .402 & .134 & .458 & 3.004 & .005 \\
\multicolumn{1}{l}{ DER } & -.227 & .110 & -.316 & -2.071 & .047 \\
\hline
\end{tabular}

Sumber: Data Penelitian, 2019

Variabel intellectual capital dalam penelitian ini berpengaruh positif pada profiabilitas, sehingga $\mathrm{H}_{1}$ diterima. $\mathrm{Hal}$ ini dapat dilihat melalui Tabel 7, di mana dalam hasil uji hipotesis memiliki koefisien regresi positif sebesar 0,402 dengan tingkat signifikansi sebesar 0,005 yang nilainya lebih kecil dibandingkan dengan taraf nyata $a=0,05$. Hal ini berarti apabila perusahaan semakin baik dalam memanfaatkan intellectual capital yang dimiliki, maka semakin tinggi pula tingkat profitabilitasnya. Hasil penelitian ini sejalan dengan resource based theory yang menyatakan bahwa jika perusahaan mampu mengelola sumber daya dan pengetahuannya dengan baik maka perusahaan tersebut akan memiliki 
keunggulan kompetitif yang akan mempengaruhi kinerjanya. Sumber daya dan pengetahuan yang dimiliki dan dikelola dengan baik oleh perusahaan, diharapkan mampu meningkatkan kinerja keuangan perusahaan. Hasil penelitian ini juga diperkuat oleh penelitian terdahulu oleh Faradina (2016) serta Mariyantini \& Putri (2018) yang menyatakan intellectual capital memiliki pengaruh positif pada kinerja keuangan perusahaan.

Berdasarkan hasil uji hipotesis yang memiliki koefisien regresi negatif sebesar 0,227 dengan tingkat signifikansi sebesar 0,047 yang lebih kecil dibandingkan dengan taraf nyata $\mathrm{a}=0,05$. Hal ini berarti leverage berpengaruh negatif pada profitabilitas, sehingga $\mathrm{H}_{2}$ diterima. Hasil penelitian ini sesuai dengan trade-off theory yang menjelaskan mengenai keseimbangan antara manfaat dan pengorbanan dalam penggunaan utang (Brigham \& Houston, 2001). Semakin tinggi tingkat utang, maka semakin tinggi pula beban tetap perusahaan sehingga akan memiliki risiko yang lebih tinggi terhadap kesulitan keuangan. Perusahaan dengan tingkat pinjaman yang tinggi akan lebih memprioritaskan untuk membayar utang daripada meningkatkan profitabilitas. Hal ini dapat menyebabkan kemampuan perusahaan dalam menghasilkan keuntungan akan semakin rendah. Hasil penelitian ini yang menyatakan leverage berpengaruh negatif pada profitabilitas juga di dukung oleh penelitian terdahulu oleh Raharja \& Putra (2016).

Penelitian ini diharapkan dapat memberikan kontribusi mengenai pengaruh intellectual capital dan leverage pada perusahaan sub-sektor asuransi yang terdaftar di Bursa Efek Indonesia Periode 2016-2018. Hasil penelitian ini yang menyatakan bahwa intellectual capital memiliki pengaruh positif pada profitabilitas dan leverage berpengaruh negatif pada profitabilitas perusahaan sub-sektor asuransi yang terdaftar di Bursa Efek Indonesia periode 2016-2018. Berdasarkan hasil tersebut, diharapkan dapat menjadi bahan pertimbangan bagi perusahaan untuk dapat mengoptimalkan intellectual capital yang dimiliki sehingga dapat menciptakan keunggulan bersaing. Perusahaan juga diharapkan untuk mempertimbangkan besarnya hutang yang dipergunakan, sehingga tidak menyebabkan kesulitan keuangan pada perusahaan.

\section{SIMPULAN}

Intellectual capital berpengaruh positif pada profitabilitas perusahaan sub-sektor asuransi yang terdaftar di Bursa Efek Indonesia tahun 2016-2018. Hal ini menunjukkan bahwa perusahaan yang memberdayakan intellectual capital secara optimal akan mempengaruhi tingkat profitabilitasnya menjadi lebih tinggi. Dalam penelitian ini menunjukkan bahwa salah elemen utama intellectual capital, yaitu human capital memperoleh hasil paling signifikan dalam mempengaruhi profitabilitas perusahaan, sehingga dapat disarankan pula bagi perusahaan dan menelitian selanjutnya agar lebih fokus terhadap hal tersebut.

Leverage berpengaruh negatif pada profitabilitas perusahaan sub-sektor asuransi yang terdaftar di Bursa Efek Indonesia tahun 2016-2018. Hal ini berarti semakin meningkat nilai DER maka profitabilitas perusahaan akan menurun. Perusahaan dengan komposisi hutang yang lebih besar akan memiliki beban tetap yang lebih tinggi sehingga perusahaan akan lebih memprioritaskan untuk membayar kewajibannya dibandingkan mencari profit. 


\section{REFERENSI}

Abhayawansa, S., Aleksanyan, M., \& Cuganesan, S. (2018). Conceptualisation OF Intellectual Capital IN Analysts' Narratives: A Performative View. Accounting, Auditing \& Accountability Journal, 31(3), 950-969. HTTPS:/ / DOI.ORG/HTTPS:/ /DOI.ORG/10.1108/ Aaaj-03-2017-2873

Downloaded

Abhayawansa, S., \& Guthrie, J. (2014). Importance OF Intellectual Capital Information: A Study OF. Australian Accounting Review, 24(1), 66-83. HTTPS:/ /DOI.ORG/10.1111/AUAR.12012

Andreani, N. L. M., \& Putra, I. M. P. D. (2019). Pengaruh Leverage DAN Ukuran Perusahaan Terhadap Profitabilitas Dengan Modal Intelektual Sebagai Pemoderasi. E-Jurnal Akuntansi Universitas Udayana, 28(2), 1435-1463. HTTPS:/ / DOI.ORG/HTTPS:/ /DOI.ORG/10.24843/Eja.2019.V28.I02.P24 Pengaruh

Ariyani, N. K. S., \& Wirakusuma, M. G. (2018). Pengaruh Modal Intelektual Pada Nilai Perusahaan Dengan Kinerja Keuangan Sebagai Variabel Mediasi. EJurnal Akuntansi Universitas Udayana, 25(1), 464-496. HTTPS:/ / DOI.ORG/HTTPS:/ /DOI.ORG/10.24843/Eja.2018.V25.I01.P18 Pengaruh

Brigham, F., \& Houston, J. (2001). Manajemen Keuangan (Kedelapan). Jakarta: Erlangga.

Chen, L. J., \& Chen, S. Y. (2011). The INFLUENCE OF PROFITABILITY ON FIRM VALUE WITH CAPITAL STRUCTURE AS THE MEDIATOR AND FIRM SIZE AND INDUSTRY AS MODERATORS. Investment Management AND Financial Innovations.

Csr, P., Perusahaan, U., Khafa, L., \& Laksito, H. (2015). Pengaruh Csr, Ukuran Perusahaan, Leverage, Dan Keputusan Investasi Pada Kinerja Keuangan Perusahaan Dan Nilai Perusahaan. Diponegoro Journal OF Accounting, 4(4), 207-219.

Damayanti, D. F., Handayani, S. R., \& Nurlaily, F. (2018). Pengaruh Market Value Ratio, Leverage DAN Profitabilitas Terhadap Future Investment ( Studi Pada Perusahaan Subsektor Asuransi Yang Terdaftar Di Bei Periode Tahun 2010-2016). Jurnal Administrasi Bisnis (Jab), 61(2), 20-29.

Dewi, A. A. A. T. W., \& Wirawati, N. G. P. (2018). Pengaruh Profitabilitas PADA Nilai Perusahaan DENGAN Corporate Social Responsibility Sebagai Variabel Intervening. E-Jurnal Akuntansi Universitas Udayana, 22(2), 15571585.

HTTPS://DOI.ORG/Doi: HTTPS:/ /DOI.ORG/10.24843/Eja.2018.V22.I02.P27 Pengaruh

Faradina, I. (2016). Pengaruh Intellectual Capital Dan Intellectual Capital Disclosure Terhadap Kinerja Keuangan Perusahaan. E-Jurnal Akuntansi, 15(2), 1623-1653,.

Fitriasari, N. M. A. D., \& Sari, M. M. R. (2019). Pengaruh Intellectual Capital Pada Nilai Perusahaan Dengan Kinerja Keuangan Sebagai Variabel Intervening. E-Jurnal Akuntansi Universitas Udayana, 26(3), 1717-1740. HTTPS:/ / DOI.ORG/HTTPS:/ /DOI.ORG/10.24843/Eja.2019.V26.I03.P02

Hari Raharja, K., \& Dwiana Putra, I. (2016). Risiko Kredit Sebagai Pemoderasi 
Pengaruh Leverage Dan Ukuran Perusahaan Terhadap Nilai Perusahaan. EJurnal Akuntansi, 16(1), 645-657.

Isbanah, Y. (2015). Pengaruh Esop, Leverage, AND Ukuran Perusahaan Terhadap Kinerja Keuangan Perusahaan Di Bursa Efek Indonesia. Jurnal Riset Ekonomi Dan Manajemen, 28. HTTPS:/ / DOI.ORG/10.17970/JREM.15.150103.ID

Mariyantini, N. L. P. N., \& Putri, I. G. A. M. A. D. (2018). Pengaruh Csr DAN Intellectual Capital Pada Kinerja Keuangan Perbankan Yang Terdaftar DI Bei Periode 2013-2016. E-Jurnal Akuntansi Universitas Udayana, 23(2), 11711200.

HTTPS:/ / DOI.ORG/HTTPS:/ /DOI.ORG/10.24843/Eja.2018.V23.I02.P14 Pengaruh

Mondal, A., \& Ghosh, S. K. (2012). Intellectual CAPITAL AND FINANCIAL PERFORMANCE OF Indian BANKS. Journal OF Intellectual Capital, 13(4), 515-530. HTTPS://DOI.ORG/10.1108/14691931211276115

Prastuti, M. C., \& Budiasih, I. G. A. N. (2019). Pengaruh Corporate Social Responsibility DAN Intellectual Capital Pada Kinerja Keuangan. E-Jurnal Akuntansi Universitas Udayana, 27(2), 1365-1493. HTTPS:/ /DOI.ORG/HTTPS:/ /DOI.ORG/10.24843/Eja.2019.V27.I02.P20 Pengaruh

Sawarjuwono, T., \& Kadir, A. P. (2003). Intellectual Capital: Perlakuan , Pengukuran DAN Pelaporan. Jurnal Akuntansi Dan Keuangan, 5(3), 35-57. HTTPS:/ / DOI.ORG/HTTPS:/ /DOI.ORG/10.9744/JAK.5.1.PP.\%2035-57

Stewart, T., \& Ruckdeschel, C. (1998). Intellectual CAPITAL: The NEW WEALTH OF ORGANIZATIONS. Performance Improvement. HTTPS:/ /DOI.ORG/10.1002/PFI.4140370713

Sugiyono, P. D. (2018). Metode Penelitian Kuantitatif, Kualitatif, DAN RED. Bandung: Cv Alfabeta.

Suwito, E., \& Herawati, A. (2005). Analisis Pengaruh Karakteristik Perusahaan Terhadap Tindakan Perataan Laba Yang Dilakukan Oleh Perusahaan Yang Terdaftar Di Bursa Efek Jakarta. Sna Viii Solo, 136-146. 